\title{
In the Camp and on the March: Military Manuals as Sources for Studying Premodern Public Health
}

\author{
G. GELTNER * \\ Department of History, University of Amsterdam, Kloveniersburgwal 48, \\ 1012 CX Amsterdam, The Netherlands
}

\begin{abstract}
Historians tend to view public health as a quintessentially modern phenomenon, enabled by the emergence of representative democracies, centralised bureaucracies and advanced biomedicine. While social, urban and religious historians have begun chipping away at the entrenched dichotomy between pre/modernity that this view implies, evidence for community prophylactics in earlier eras also emerges from a group of somewhat unexpected sources, namely military manuals. Texts composed for (and often by) army leaders in medieval Latin Europe, East Rome (Byzantium) and other premodern civilisations reflect the topicality of population-level preventative healthcare well before the nineteenth century, thereby broadening the path for historicising public health from a transregional and even global perspective. Moreover, at least throughout the Mediterranean world, military manuals also attest the enduring appeal of Hippocratic and Galenic prophylactics and how that medical tradition continued for centuries to shape the routines and material culture of vulnerable communities such as armies.
\end{abstract}

Keywords: Public health history, Global health history, Military medicine, Biopolitics, Periodisation

During the early nineteenth century, armies began to do away with tents, a trend whose drawbacks military theoretician Carl Von Clausewitz (1780-1831) felt compelled to stress. In his acclaimed Vom Kriege (On War) the Prussian certainly sympathised with generals who chose to devote their limited horsepower to carrying several canons instead of lugging thousands of small shelters. Nonetheless, he reminded his readers that the decision must take at least two important considerations into account. First, tents reduce armies' impact on their environment, whether built, cultivated or pristine, which in turn had physical,

* Email address for correspondence: g.geltner@uva.nl

For their comments on earlier drafts, bibliographical suggestions and copies of works in progress, I am grateful to Mieke Aerts, Sander Govaerts, John Haldon, Jonathan Harris, Mayke de Jong, Samuël Kruizinga, Piers Mitchell, Carole Rawcliffe, Justin Stearns, James Symonds, Claire Weeda and the journal's editors and anonymous reviewers. In citing primary sources in translation, the text follows the original text and therefore involves occasional orthographical discrepancies between US and UK English. Funding has been provided by the European Research Council (grant no. 724114) as part of the Premodern Healthscaping Project (https://prem odernhealthscaping.hcommons.org/). 
economic and political implications. Secondly and no less important, tents influenced soldiers' health:

The protection afforded by a roof of a cheap canvas may not be much, but over a period of time it is a relief that will be missed by the troops when it is not there. For a single day the difference is slight; a tent gives little shelter against wind and cold, and is far from rainproof. But a slight difference becomes a major one when the situation recurs two or three hundred times a year. Increased losses due to sickness will naturally result. ${ }^{1}$

Camps' material constitution, in other words, has to be aligned with an army's strategic goals, since it too impacts soldiers' health and hence their ability to wage war. This aspect of strategy began to ring especially true as campaigns became increasingly drawn-out affairs (indeed, this was one of Von Clausewitz's overriding concerns). Given that armies marched and stayed put for ever longer periods, coming to terms with environmental factors and thinking preventatively grew more urgent. ${ }^{2}$

Elsewhere in his magnum opus, Von Clausewitz revisits the theme of prophylactic healthcare in non-combat situations. For instance, he notes that a marching army faces high attrition rates in the absence of steady shelter, food supply, medical attention and comfort in movement. What is the right amount of rest on the march and how best to organise it were clearly being recognised as consequential to soldiers' health:

It is commonly said that a long period of rest is not good for the physical health of an army, and that there is more sickness at such times than during periods of moderate activity. It may well be that sickness does occur when soldiers are crowded together in cramped quarters, but it can occur just as easily in billets along the march. ${ }^{3}$

Von Clausewitz was not only pro-tent, then, but also an advocate of breaking up marches to help soldiers recover from their exertions. He saw rest as paramount for maintaining a healthy routine, arguably a more crucial measure than other, decidedly preventative interventions, which would ensure airflow in the barracks and keep soldiers to a schedule of physical exercise. Whatever the merits of his advice, he consciously waded into an ongoing - indeed, quite longstanding - debate.

\section{A Community at Risk}

Military theoreticians have long regarded physical objects, such as tents, human regimens including respite and diet, and other standards meant to keep armies healthy and safe outside of combat, as strategic assets. As Von Clausewitz put it, 'It is not unusual that a victorious army suffers greater losses from sickness than from battle': a painful truth confronting most armies until the mid-twentieth century. ${ }^{4}$ If so, studying military manuals, of which Vom Kriege is among the most feted but hardly the first, promises to enrich the social and intellectual history of community health, that is interventions meant to promote health and fight disease at a population level, whatever defined a group as such

\footnotetext{
${ }^{1}$ Carl Von Clausewitz, Vom Kriege (Berlin: Dümmlers Verlag, 1832), Book 5, ch. 9. Quoted here from On War, Michael Howard and Peter Paret (trans.) (Princeton: Princeton University Press, 1976), 312-13. Contrary to the author's implication, however, simple mud and straw huts rather than tents were arguably more common accommodations for soldiers on the move. See Sander Govaerts, 'Mosasaurs. Armies and their Influence on Ecosystems in the Meuse Region, 1300-1850' (unpublished PhD dissertation, University of Amsterdam, 2019), ch. 6.

${ }^{2}$ See also Von Clausewitz, Vom Kriege, Book 5, ch. 14 (Subsistence).

${ }^{3}$ Ibid., Book 5, ch. 12 (322).

${ }^{4}$ Ibid., Book 3, ch. 12 (207). According to Richard A. Gabriel and Karen S. Metz, A History of Military Medicine, Vol. 2 (New York: Greenwood Press, 1992), 1:2, 'Until the twentieth century all armies with few exceptions suffered far more casualties to disease acquired through contaminated food and water than they did on the battlefield'.
} 
and however loosely or temporarily it was bound together beyond a certain physical proximity. From the standpoint of public health's deeper history, moreover, military treatises constitute a rarely-explored corpus, one that can be examined from a transregional and even global perspective given the steady output and survival of comparable sources from Europe, the Eastern Mediterranean, Asia and elsewhere. Even by comparison to the related genre of medieval travel literature, whose insights into public health have at least caught some scholars' attention, military manuals remain virtually unknown as sources for the history of premodern prophylactics. ${ }^{5}$

Certainly, historians of modern warfare, colonialism and imperialism have repeatedly remarked how instrumental armies were, as witting and unwitting agents, in promoting preventative medicine as well as impacting the health of militaries and civilian populations outside of combat. ${ }^{6}$ In doing so they have overcome an understandable tendency to see armies mainly as machines of death and destruction rather than also as promoters of health and as stakeholders in environmental protection programmes. ${ }^{7}$ By comparison, the smaller cohort of public health historians studying premodern societies usually suffer from a scarcity of sources, on the one hand, ${ }^{8}$ and armies' common (modern) reputation for hygienic apathy, on the other. Furthermore, despite premodern generals' and military medical personnel's explicit mandate to conserve the health of armies, historians tend to focus on the curative efforts of coeval army pharmacists, barber-surgeons and physicians, offering limited insights into the latter's (and others') preventative actions off the battlefield, where soldiers spent most of their time. ${ }^{9}$

Examining prophylactic advice in early military manuals therefore provides a more granular view, complementing recent efforts to reconstruct preventative practices in ancient, medieval and early modern societies, which have largely dealt with monasteries and especially cities. ${ }^{10}$ Scholars tilling the field of premodern public health have found

\footnotetext{
${ }^{5}$ Peregrine Horden, 'Regimen and travel in the Mediterranean', in Renate Schlesier and Ulrike Zellmann (eds), Mobility and Travel in the Mediterranean from Antiquity to the Middle Ages (Münster: LIT Verlag, 2004), 117-31. As Horden shows (129-30), the genres logically overlap in the context of medieval crusading.

${ }^{6}$ Key studies include Daniel R. Headrick, The Tools of Empire: Technology and European Imperialism in the Nineteenth Century (New York and Oxford: Oxford University Press, 1981), 58-79; David Arnold, Imperial Medicine and Indigenous Societies (Manchester: Manchester University Press, 1988); Philip D. Curtin, Disease and Empire: The Health of European Troops in the Conquest of Africa (Cambridge: Cambridge University Press, 1998).

${ }^{7}$ Examples of the ecological turn in military studies include Alfred W. Crosby, Ecological Imperialism: The Biological Expansion of Europe, 900-1900 (New York: Cambridge University Press, 1986); Esther Blom, et al. (eds), Nature in War: Biodiversity Conservation during Conflicts (Amsterdam: Nederlandse Commissie voor Internationale Natuurbescherming, 2000); Richard P. Tucker and Edmund Russell (eds), Natural Enemy, Natural Ally: Toward an Environmental History of War (Coravallis, OR: Oregon State University Press, 2004); J.R. McNeill, Mosquito Empires: Ecology and War in the Greater Caribbean, 1620-1914 (Cambridge: Cambridge University Press, 2010).

${ }^{8}$ Carole Rawcliffe, 'Sources for the study of public health in the medieval city', in Joel T. Rosenthal (ed.), Understanding Medieval Primary Sources: Using Historical Sources to Discover Medieval Europe (London: Routledge, 2012), 177-95.

${ }^{9}$ An exception here is Lluís Cifuentes and Luis García Ballester, 'Els professionals sanitaris de la Corona d'Aragó en l'expedició militar a Sardenya de 1354-55', Arxiu de textos catalans antics, 9 (1990), 183-214. More typical, but for that matter no less accomplished, are several contributions in Larissa Tracy and Kelly DeVries (eds), Wounds and Wound Repair in Medieval Culture (Leiden: Brill, 2015).

10 To offer only a few recent examples dealing with several European regions: Barbara Harvey, Living and Dying in England, 1100-1540: The Monastic Experience (Oxford: Clarendon Press, 1993); Angela Montford, Health, Sickness, Medicine and the Friars in the Thirteenth and Fourteenth Centuries (London and New York: Routledge, 2004); Annemarie Kinzelbach, 'Infection, Contagion, and Public Health in Late Medieval German Imperial Towns', Journal of the History of Medicine and Allied Sciences, 61 (2006), 369-89; Kirsty Wilson Bowers,
} 
rich evidence to challenge an entrenched view of population-level interventions as mere byproducts of modernity, rendered possible thanks to representative governments and advanced science, and relevant due to the proliferation of cities and massive environmental degradation. Carole Rawcliffe's Urban Bodies (2013), most notably, marshals abundant material and written evidence illustrating how urban residents, guilds and governments in medieval England devised prophylactic policies and pursued them, including well before the onset of the second plague pandemic in the mid-fourteenth century. ${ }^{11}$ The latter point is especially salient in rejecting an ostensibly benign recognition of premodern public health practices, if only as a reaction to plague by otherwise apathetic civilisations. Indeed, as Agostino Paravicini Bagliani has argued, a revival of learned medicine in eleventhcentury Italy undergirded the practice of community prophylactics at the papal court, including the curia's pursuit of healthy locations when Rome was deemed particularly dangerous, and the dissemination of preventative practices through the imposition of various measures upon host towns. ${ }^{12}$ These and other successful attempts to historicise community prophylactics, however, make little use of evidence related to military life.

Indeed, although armies' size and the scale of military logistics have changed dramatically at least in western Europe since the Napoleonic Wars, ${ }^{13}$ their welldocumented struggle against disease in earlier eras can help frame public health as something more than just a byproduct of modernity. For militaries were scarcely isolated communities of prophylactic practice; the medical theories informing their actions may well have been shaped by those of urban, monastic and other communities, and their practices (for instance of burial, exercise and sourcing food and water) could have inspired civic leaders to follow suit. Yet it is precisely this kind of integrated and dynamic perspective that many historians of premodern public health still mostly lack. ${ }^{14}$

Plague and Public Health in Early Modern Seville (Rochester, NY: University of Rochester Press, 2013); John Henderson, 'Public health, pollution and the problem of waste disposal in early modern Tuscany', in Simonetta Cavaciocchi (ed.), Le interazioni fra economia e ambiente biologico nell'Europa preindustriale. Secc. XIIIXVIII (Florence: Firenze University Press, 2010), 373-82; Jane L. Stevens Crawshaw, Plague Hospitals: Public Health for the City in Early Modern Venice (Farnham, Surrey: Ashgate, 2012). For a fuller bibliography, see G. Geltner and Janna Coomans (eds), 'The History of Public Health in Pre-Industrial Societies: A Bibliography': https://premodernhealthscaping.hcommons.org/documents/ (last accessed 26 August 2018).

${ }^{11}$ Carole Rawcliffe, Urban Bodies: Communal Health in Late Medieval English Towns and Cities (London: Boydell, 2013). See also Leona J. Skelton, Sanitation in Urban Britain, 1560-1700 (London: Routledge, 2015); G. Geltner, Roads to Health: Infrastructure and Public Wellbeing in Later Medieval Italy (Philadelphia: University of Pennsylvania Press, forthcoming); Janna Coomans, 'In Pursuit of a Healthy City: Sanitation and the Common Good in the Late Medieval Low Countries' (unpublished PhD Dissertation, University of Amsterdam, 2018).

12 Agostino Paravicini Bagliani, Il corpo del Papa (Turin: Einaudi, 1994), 257-78. Integrating evidence from military tactics, however, challenges the author's causal relationship and chronology, even with regard to Italy. See Geltner, Roads to Health.

${ }^{13}$ Beatrice Heuser, The Evolution of Strategy: Thinking War from Antiquity to the Present (Cambridge: Cambridge University Press, 2010), 113-70; John Childs, 'The military revolution I: the transition to modern warfare' and 'The Military Revolution II: Eighteenth-Century War', both in Charles Townsend (ed.), The Oxford History of Modern War (Oxford: Oxford University Press, 2005), 20-40 and 41-54, respectively.

${ }^{14}$ See, however, the pioneering work of Piers D. Mitchell, 'Challenges in the study of health and disease in the crusaders', in Marina Faerman et al. (eds), Faces from the Past: Diachronic Patterns in the Biology and Health Status of Human Populations of the Eastern Mediterranean, British Archaeological Reports (British Series, 1603) (Oxford: Archaeopress, 2007), 205-12; Piers D. Mitchell, 'Combining palaeopathological and historical evidence for health in the crusades', in Martin J. Smith and Megan B. Brickley (eds), Proceedings of the 8th Annual Conference of the British Association for Biological Anthropology and Osteoarchaeology, British Archaeological Reports (International Series, 1743) (Oxford: Archaeopress, 2008), 9-16; and Govaerts, op. cit. (note 1). 
To begin developing a corrective, the present article draws on a number of texts produced by the civilisations of medieval western Europe and East Rome (Byzantium), before briefly suggesting further research possibilities afforded by comparable works hailing from the Islamicate Mediterranean and East Asia. Far from exhaustive, the selection reflects my linguistic limitations as well as the current state of publication and especially translation of relevant sources, even when casting a wide geographical and chronological net. Since this is an argument based predominantly on a single genre (or a cluster of related genres), the selected texts had to meet one basic criterion, namely that they were ostensibly written as a military commander's guidebook (as distinct, for instance, from a medical manual that also dealt with battle injuries), and regardless of the author's formal training or perceived authority among contemporaries. ${ }^{15}$

Two preliminary observations are in order before delving into these texts. First, as a corpus, they display important points of resemblance. Throughout the long period under consideration, tactical manuals were mostly written for and by male military-political elites, the work of Christine de Pizan's (1364-1430; see below) offering a unique as well as partial exception. Authors and readers thus shared access - within a given society to a medical-cultural archive, a health literacy common to the intended audiences of the original works. The medical-theoretical knowledge upon which these texts drew usually remains implicit, but it can be surmised from coeval and earlier medical and naturalphilosophical literature, works which themselves tended to circulate in similar groups. The present article's focus allowed for only the briefest treatment of questions regarding each text's dating, the details of its transmission and reception, its intended audience(s), the original compilation methods and linguistic peculiarities. Yet none of these shortfalls obscures the fact that Greece and Rome's European, Asian and North African intellectual heirs shared a medical tradition associated with Hippocrates (c. 460-c. 370 BC) and his school in Greek Antiquity and furthered by Galen (129-200? AD) and his followers' commentaries. ${ }^{16}$ Diverse medical, religious and natural-philosophical traditions likely undergirded military prophylactics in other regions as well, but these too fall beyond the scope of the present study. ${ }^{17}$

\footnotetext{
${ }^{15}$ Conor Whately, 'The genre and purpose of military manuals in late antiquity', in Geoffrey Greatrex and Hugh Elton (eds), with the assistance of Lucas McMahon, Shifting Genres in Late Antiquity (Farnham: Ashgate, 2015), 249-61. See also David Whitehead, 'Fact and Fantasy in Greek Military Writers', Acta Antiqua Academiae Scientiarum Hungaricae, 48 (2008), 139-55.

${ }^{16}$ Medieval Islamic Medicine: Ibn Ridwān's Treatise 'On the Prevention of Bodily Ills in Egypt', Michael W. Dols (ed.), Adil S. Gamal (trans.), Comparative Studies of Health Systems and Medical Care, 9 (Berkeley and London: University of California Press, 1984); Nancy Siraisi, Medieval and Renaissance Medicine: An Introduction to Knowledge and Practice (Chicago: University of Chicago Press, 1990), 128-30; Dorothy Porter, Health, Civilisation and the State: A History of Public Health from Ancient to Modern Times (London and New York: Routledge, 1999), 9-60; Peter E. Pormann and Emilie Savage-Smith, Medieval Islamic Medicine (Washington, DC: Georgetown University Press, 2007); Jacques Jouanna, 'Air, miasma and contagion in the time of Hippocrates and the survival of miasmas in post-hippocratic medicine (Rufus of Ephesus, Galen and Palladius)', in Philip van der Eijk (ed.), Greek Medicine from Hippocrates to Galen. Selected Papers of Jacques Jouanna, Neil Allies (trans.) (Leiden: Brill, 2012), 121-36; Justin K. Stearns, Infectious Ideas: Contagion in Premodern Islamic and Christian Thought in the Western Mediterranean (Baltimore: The Johns Hopkins University Press, 2011); Petros Bouras-Vallianatos and Sophia Xenophontos (eds), Greek Medical Literature and its Readers: From Hippocrates to Islam and Byzantium (Abingdon and New York: Routledge, 2018).

${ }^{17}$ See, however, Guido Majno, The Healing Hand: Man and Wound in the Ancient World (Cambridge, MA, and London: Harvard University Press, 1975), 235, 242-43; A.M. Acharya, 'Military Medicine in Ancient India', Bulletin of the Indian Institute of History of Medicine, 6 (1963), 50-57; Thomas Cleary, The Japanese Art of War: Understanding the Culture of Strategy (Boston and London: Shambhala, 2005).
} 
Secondly, if a modicum of shared health literacy was to be expected among the intended readers of military manuals, that hardly meant that the prophylactic framework supporting them was everywhere and always the same. Premodern medicine was a dynamic and evolving field of expertise even within medieval Europe and East Rome, and there is no reason to assume that coeval cultures across a vast swath of time and territory shared immutable principles. ${ }^{18}$ Nor did premodern armies face a static and identical theatre of war, either in terms of climate and terrain or the scale and capacity of their foes. Latin crusaders' efforts in an unfamiliar Levant since the later eleventh century is a well-documented case in point, as are the experiences of Mongol armies, fighting from Gaza to Java, in the thirteenth century. Nonetheless, mining this long era's sources for preventative insights and concerns challenges medieval armies' reputation, and that of premodern cultures more broadly, as ignorant or negligent when it came to public hygiene. For tactical manuals attest a sustained effort at least by certain learned elites to consider population-level threats also outside of armed conflict as pertinent to commanders' and medical personnel's remits, including many hundreds if not thousands of non-elites and non-combatants. Manuals' ongoing production of knowledge thus played a major and often overlooked role in promoting biopolitical agendas in a period and across regions rarely associated with them. This has important implications regarding one aspect of the pre/modern divide that historians seldom interrogate, and which will be discussed in the conclusion.

\section{Western Europe}

In Latin Europe, discussions of preventative healthcare among armies build on and echo two influential treatises composed in Late Antiquity, namely Onasander's Strategikos (first century) and, arguably to a greater extent, Vegetius' Epitoma rei militaris (late fourth or early fifth century). ${ }^{19}$ Both texts, also foreshadowing much later manuals, assume that military life entailed a regular confrontation with community-broad threats, be it during training, at times of peace, at war or in the immediate aftermath of battle. As Onasander warned the aspiring Roman general (his treatise was formally dedicated to Quintus Veranius Nepos [d. 57], the future governor of Britain), safe encampment depends on more than palisades, a ditch and vigilant guards. Indeed, a paramount concern is to identify a location 'that is not marshy, nor damp; for such places by their rising vapours and rank smell bring disease and infection to the army, and both impair the health of many and kill many, so that the soldiers are left few in number and weakened in strength'. ${ }^{20}$

Onasander argued that polluted air (miasma) causes diseases that were just as lethal to soldiers as, and indeed often more than, any enemy they faced in battle. ${ }^{21}$ In doing so,

18 The same dynamism has been illuminated for other regions. See, for instance, Andrew Edmund Goble, Confluences of Medicine in Medieval Japan: Buddhist Healing, Chinese Knowledge, Islamic Formulas, and Wounds of War (Honolulu: University of Hawaii Press, 2011).

${ }^{19}$ Of the two extant military manuals that predate both these texts, I was unable to access Arrian of Nicomedia's Techne Taktike (136/37 AD), which has not been translated from the Greek into Latin or any other European language; and Aelianus' second-century Tactics does not deal with any aspect of health or medicine.

20 Onasander, Strategikos 8.2, in Aeneas Tacticus, Asclepiodotus and Onasander, ed. and trans. The Illinois Greek Club, Loeb Classical Library 156 (Cambridge, MA: Harvard University Press, 1928), 405.

21 Thousands of crusaders died from non-combat related afflictions according to Piers D. Mitchell, Medicine in the Crusades: Warfare, Wounds and the Medieval Surgeon (Cambridge: Cambridge University Press, 2004), 1-3. For comparable figures in Antiquity, see Nathan Stewart Rosenstein, Rome at War: Farms, Families, and Death in the Middle Republic (Chapel Hill, NC: University of North Carolina Press, 2004), 130-31. For further ramifications, see Friedrich Prinzing, Epidemics Resulting from Wars (Oxford: Clarendon Press, 1916). 
he harkened back to the dictums of Hippocratic medicine, and in particular to the treatise known as Airs, Waters, Places. The work, most likely written by Hippocrates himself, inventories cities' vulnerabilities as a function of their exposure to the elements of wind (air), water and humidity. While allowing for variation among people's physiques and adaptability, as well as climactic diversity, the work nonetheless typified the impact of, for instance, cold wind or brackish water on communities as a whole. The unhealthiest cities, it maintained, are those having only a western exposure, which leaves them bereft of the most beneficial winds while being punished by the sun's strongest rays. The author also claimed that waters that are 'marshy, standing and stagnant' in the summer become 'unhealthy and bilious' and in winter can be 'very conducive to phlegm and sore throats' ${ }^{22}$ It was by working within this paradigm and drawing lessons from urban experiences that Onasander later sought to optimise a camp's situation and make life in it sustainable for all.

Three centuries after Onasander, the otherwise unknown Vegetius stressed in similar terms (albeit now in Latin, which explains his work's greater popularity in western Europe) how a general's choice of site must be informed by considerations of human and non-human factors:

[Camps'] situation should be strong by nature, and there should be plenty of wood, forage and water. If the army is to continue in it any considerable time, attention must be had to the salubriousness of the place. The camp must not be commanded by any higher grounds from whence it might be insulted or annoyed by the enemy, nor must the location be liable to floods which would expose the army to great danger. The dimensions of the camps must be determined by the number of troops and quantity of baggage. ${ }^{23}$

To Vegetius, then, military camps' resilience relied on both topographical and humanrelational aspects. ${ }^{24}$ Yet the choice of a promising location had to be reinforced by encouraging salubrious behaviors as well. Here too Vegetius offers a complex assessment befitting a dynamic situation. For the health of troops

depends on the choice of situation and water, on the season of the year, medicine and exercise. As to the situation, the army should never continue in the neighborhood of unwholesome marshes any length of time, or on dry plains or eminences without some sort of shade or shelter. In the summer, the troops should never encamp without tents. And their marches, in that season of the year when the heat is excessive, should begin by break of day so that they may arrive at the place of destination in good time. Otherwise they will contract diseases from the heat of the weather and the fatigue of the march. In severe winter they should never march in the night in frost and snow, or be exposed to want of wood or clothes. A soldier, starved with cold, can neither be healthy nor fit for service. The water must be wholesome and not marshy. Bad water is a kind of poison and the cause of epidemic distempers. ${ }^{25}$

Climactic, physical as well as human factors thus helped define the health of an army, alongside individuals' capacity to perform their tasks.

Like Onasander before him, Vegetius too drew on Hippocratic insights, either directly or as refracted through later interpreters. The latter included Galen's or Galenic commentaries on the Hippocratic corpus, from which Onasander could not have benefited. Galenism also preferred the efficiency of prevention (hygeia) to curing (panacea), and it considered in this respect environmental conditions to have a major impact on humans, as individuals and groups. This meant that location mattered, especially in combination with a people's

\footnotetext{
${ }^{22}$ Hippocrates, Airs Waters Places, VI and VII, in W.H.S. Jones (ed. and trans.), Ancient Medicine, Loeb Classical Library 147 (Cambridge, MA: Harvard University Press, 1923), 83 and 85, respectively.

${ }^{23}$ R. Flavius Vegetius, De re militari, M.D. Reeve (ed.) (Oxford: Oxford University Press, 2004), I, xxii (25-26). Translations here and below from Epitome of Military Science, 2nd edn, N.P. Milner (trans.) (Liverpool: Liverpool University Press, 1996).

${ }^{24}$ I am leaving aside another relevant form of knowledge, namely military veterinary medicine, which may well have served governments and butchers in establishing whether meat sold on the urban market was spoiled or not. 25 Vegetius, op. cit. (note 23), III, ii (67).
} 
typical humoral constitution. ${ }^{26}$ Galenism likewise stressed the role played by human behaviours and activities in obtaining humoral balance (eukrasia or symmetria). These were collectively known as the six non-naturals: air quality; sleep and wakefulness; exercise and rest; food and drink; secretion and excretion; and mental affections. ${ }^{27}$ The perfect convergence of both types of factors (natural and non) should be reflected in the absence of disease. In military terms, this meant fitness for service, a specific display of health in what Galen called ' $[\mathrm{t}]$ he unimpaired capacity of function', ${ }^{28}$ a criterion foreshadowing the late-modern activities of daily living (ADL) index famously developed by Sidney Katz. ${ }^{29}$

Without offering a full survey of military tractates in medieval western Europe, it is clear that earlier insights' legacy lived on. ${ }^{30}$ For, whatever else Latin and later vernacular authors derived from Classical and late-antique medical thought, either through Onasander or especially Vegetius, ${ }^{31}$ they were certainly mindful of armies' vulnerability outside of combat and disseminated their predecessors' advice on how to thwart attendant dangers. To offer just a few examples from several regions: the renowned Iberian physician Arnaud of Villanova (1240?-1311) probably consulted his copy of Vegetius in counseling James II of Aragon (1267-1327) on matters of military resilience. ${ }^{32}$ Giovanni da Legnano, a late-fourteenth-century juror and author of an influential Tractatus de bello, is directly reliant upon Hippocrates, Vitruvius and above all Vegetius in reiterating the general's duty to select and maintain healthy locations for camps (ut diutius commorandum sit, loci

${ }^{26}$ Galen, Hygiene, Book 1, ch. 4, Ian Johnston (ed. and trans.), Loeb Classical Library 535 (Cambridge, MA: Harvard University Press, 2018), 11.

${ }^{27}$ L.J. Rather, 'The Six Things Non-Natural: A Note on the Origins and Fate of a Doctrine and a Phrase', Clio Medica, 3 (1968), 337-47; Luis García-Ballester, 'On the origins of the six non-natural things in Galen', in Jutta Kollesch and Diethard Nickel (eds), Galen und das hellenistische Erbe: Verhandlungen des IV. Internationalen Galen-Symposiums veranstaltet vom Institut für Geschichte der Medizin am Bereich Medizin (Charité) der Humboldt-Universität zu Berlin 18.-20. September 1989 (Stuttgart: Steiner, 1993), 105-15. García-Ballester attributes the emergence of a consolidated list to the Alexandrian school of Galenism, and credits its spread with medieval Arabic commentaries.

${ }^{28}$ Galen, op. cit. (note 26), Book 1, ch. 5 (15).

${ }^{29}$ Linda S. Noelker and Richard Browdie, 'Sidney Katz, MD: A New Paradigm for Chronic Illness and LongTerm Care', The Gerontologist, 54 (2014), 13-20.

30 The literary tradition of military manuals in the Mediterranean world of the early and central Middle Ages seems to have gravitated around Vegetius, among Latin readers, and the Greek treatises examined in the next section, in Byzantine-controlled regions. On the former see the following note and, more broadly, Guy Halsall, Warfare and Society in the Barbarian West, 450-900 (London: Routledge, 2003), 134-62; Bernard S. Bachrach, Early Carolingian Warfare: A Prelude to Empire (Philadelphia: University of Pennsylvania Press, 2001); and Leif Inge Ree Petersen, Siege Warfare and Military Organization in the Successor States (400-800 AD): Byzantium, the West and Islam (Leiden: Brill, 2013), 299-359. As these volumes show, a conservative literary approach did not necessarily mean a lack of adaptation and creativity in practice.

31 Vegetius' De re militari was by all accounts a medieval bestseller, with more than 300 extant copies of the Latin text making it perhaps the most widely circulated secular treatise of the era. The status was only reinvigorated by the rise of vernacular languages. See Charles R. Shrader, 'A Handlist of Extant Manuscripts Containing the De re militari of Flavius Vegetius Renatus', Scriptorium, 33 (1979), 280-305; Phillipe Richardot, Végèce et la culture militaire au Moyen Âge (Ve-XVe síecles) (Paris: Institut de Stratégie Comparée : Economica, 1998); Phillipe Richardot, 'L'influence de De re militari de Végèce sur la pensée militaire du XVIe siècle', Stratégique, 60 (1996), 7-27; Phillipe Richardot, 'La reception de Végèce au XVIIIe siècle: Turpin de Crissé', Stratégique, 76 (2000), 17-51; Phillipe Richardot, 'La tradition moderne du De re militari de Végèce (XVe-XVIIIe siècles)', in P. Defosse (ed.), Hommages à Carl Deroux, V: Christianisme et Moyen Âge, Néo-latin et survivance de la latinité (Brussels: Latomus, 2003), 537-44; Christopher Allmand, The De Re Militari of Vegetius. The Reception, Transmission and Legacy of a Roman Text in the Middle Ages (Cambridge: Cambridge University Press, 2011).

32 Michael R. McVaugh, 'Arnald of Villanova's Regimen Almarie (Regimen Castra Sequentium) and Medieval Military Medicine', Viator, 23 (1992), 201-14: 207, acknowledges Arnald's debt to Vegetius, a copy of whose De re militari furnished his private library, specifically as regards prophylactics. 
salubritas eligatur), by which he also meant places with a constant supply of good food, air and water. ${ }^{33}$ Christine de Pizan, in The Book of Deeds of Arms and Chivalry (1410), relies explicitly on Vegetius in discussing how 'to keep the army in good health if it stays for a long time in one place', namely by taking into consideration 'location, water, weather and exercise'. ${ }^{34}$ And Roberto Valturio (1405-1475), an Italian humanist and engineer, dedicated an entire chapter to medicine in his widely circulating De re militari (1472), which opens with a reminder that the ancients knew better than to dwell only on cures for wounds and disease in warfare: in order for an army to hunker down safely, its leader had to establish the health of the place. ${ }^{35}$ Health, in typical Galenic fashion, consists here not only in the location's fertility and the quality of resources it provides (water, vegetation, animals), but especially in its compatibility with occupiers' humoral constitution. ${ }^{36}$

To take a final example, the same approach informed Niccolò Machiavelli, whose sixth book (of seven) On the Art of War (1519-1520) is devoted to discussing the army's rest. A stronghold, he argues, is rendered secure by nature or art (forte lo fa o il sito, o l'arte), that is thanks to location or human intervention. ${ }^{37}$ The Greeks, in his analysis, preferred the former, while the Romans tended to espouse the latter, which gave them the advantage of being able to supplement a potentially imperfect site with defensive artifice, including an internal organisation of space congenial to good communication, swift movement and timely response. The Romans, moreover, sought to position themselves in a salubrious place (luogo sano) to begin with, by avoiding swampy areas or those exposed to harmful winds ( $i$ luoghi paludosi, o esposti a'venti nocivi). And they did so by engaging a kind of medical forensics familiar to any reader of Hippocrates:

For they recognized [these conditions], not so much from the quality of the site, as from the appearance of the inhabitants; so when the latter seemed to have a bad complexion, broken-winded, or hosting another infection, they did not tarry there. ${ }^{38}$

According to the tradition Machiavelli strove to emulate, the accomplished capitano also kept his army healthy and avoided diseases and hunger by allowing soldiers to rest well, to wit 'in tents... and where trees would create shade, [and] where there would be wood to allow for the cooking of food' (sotto le tende... dove sieno arbori che facciano ombra, dove sia legname da potere cuocere il cibo). Further preventative measures to be maintained on the march included obviating extreme heat in the summer and snow and ice in the winter. And should these measures fail, and the men become sick, the general

\footnotetext{
33 Giovanni da Legnano, Tractatus de bello, de represaliis et de duello, Thomas Erskine Holland (ed.) (Oxford: Oxford University Press for the Carnegie Institution, 1917), ch. 19 (96). See also da Legnano's elaborate metaphorical use of war as a disease meant to cleanse a society suffering from humoral excesses in ibid., ch. 10 (85-90). The treatise was the basis for yet another key text on the art of war, namely Honore Bonet's The Tree of Battles, G.W. Coopland (ed. and trans.) (Liverpool: The University of Liverpool Press, 1949). For the parallel passages, see Book 4.1 and 9 (125-26 and 131-32, respectively).

${ }^{34}$ Christine de Pizan, The Book of Deeds of Arms and of Chivalry, 1.14, Charity Cannon Willard (ed.), Sumner Willard (trans.) (University Park, PA: The Pennsylvania State University Press, 1999), 42-43. As the same chapter illustrates, De Pizan, an auto-didact as well as the daughter of a physician and astrologer, was familiar with humoral medicine. While she is hardly unique among medieval women in the latter respect, she remains the only known female author of a military treatise. See also Beatrice Heuser, Strategy before Clausewitz: Linking Warfare and Statecraft (London and New York: Routledge, 2017), ch. 2.

35 [Roberto] Valturio, De re militari, in Umanesimo e arte della guerra tra medioevo e rinascimento (Rimini and Milan: Guaraldi and Y. Press, 2006): 'De medicina' I (78).

36 Ibid.: 'quam si propter locorum discrepantiam terrarumque dissimiles proprietates percipere haud quaquam poterant et phama et incolentium dispositione corporum atque eorum colore facile consequebantur' (78).

${ }^{37}$ Niccolò Machiavelli, I sette libri dell'Arte della guerra (Venice: G. Pasquali, 1769), 219.

${ }^{38}$ Ibid., 243.
} 
is to let them be cured by a physician, for he has 'no recourse when he has to fight with disease as well as with an enemy' (perchè uno capitano non ha rimedio, quando egli ha a combattere con le malattie e col nemico). ${ }^{39}$ Mindfully following in the footsteps of his ancient predecessors, and foreshadowing principles still invoked by much later tacticians, Machiavelli too argued that prevention was the preferred path to armies' health.

\section{East Rome}

As the above examples begin to convey, and contrary to premodern armies' reputation for hygienic apathy, authors of military manuals throughout the eras known today as Antiquity, the Middle Ages and the Renaissance paid close and regular attention to community prophylactics. And what is true for western Europe certainly applies to East Rome, home to an arguably richer tradition of military literature, at least for the early and central Middle Ages, which likewise drew on the preventative insights of Onasander's Strategikos and Vegetius' Epitoma, among other ancient authorities. ${ }^{40}$ For instance, the influential late sixth-century text known today as Maurice's Strategikon (12.B.22) advises:

Healthy, clean places should be chosen for camps, and we should not stay too long in one spot, unless the air and the availability of supplies are more advantageous. Otherwise disease can spread among the troops. It is very important that sanitary needs not be taken care of inside the camp, but outside because of the disagreeable odor, especially if there is some reason for the army to remain in one place... [T] he horses must not be watered [in the river] above the camp. If they are, their trampling around will make the water muddy and useless.... If it is a small stream, water the horses from buckets. ${ }^{41}$

In keeping with that tradition, the anonymous East Roman author of a Treatise on Strategy (eighth century) explained that the security of strongholds relies on more than their walls' thickness. He accordingly encouraged the ambitious general to investigate whether local water 'is safe to drink and if there is enough to supply the population of the city', as well as 'whether the [surrounding] country produces enough food', before embarking on a construction campaign. ${ }^{42}$ Subsequently, treatises such as the Apparatus bellicus (tenth century) continued to share earlier works' concern for ensuring water purity to protect the overall health of soldiers. ${ }^{43}$ And the anonymous, late tenth-century Treatise on Skirmishing (5.6-8) likewise warns against horses muddying the water, 'which could cause serious harm to the men and place them in real difficulty'. ${ }^{4}$

39 Ibid., 244.

${ }^{40}$ A recent discussion on their influence takes place in the notes to John Haldon, A Critical Commentary on The Taktika of Leo VI, Dumbarton Oaks Studies 44 (Washington, DC: Dumbarton Oaks, 2014), 10-22, 31-36, 168-72 and passim.

${ }^{41}$ Maurice's Strategikon: Handbook of Byzantine Military Strategy, George T. Dennis (ed. and trans.) (Philadelphia: University of Pennsylvania Press, 1984), 160.

42 Anonymous, Treatise on Strategy, 10:6-11, 17-18, in George T. Dennis (ed. and trans.), Three Byzantine Military Treatises (Washington, DC: Dumbarton Oaks, 1985), 31. Dennis follows an earlier tendency to date the work to the sixth century, but the more recent consensus has pushed the work two centuries later. See Constantine Zuckerman, 'The Compendium of Syrianus Magister', Jahrbuch der Österreichischen Byzantinistik, 40 (1990): 209-24.

${ }^{43}$ Constantine Zuckerman, 'Chapitres peu connus de l'apparatus bellicus', Travaux et mémoires du Centre de recherches d 'histoire et civilisation de Byzance, 12 (1994), 359-89: 372.

${ }^{44}$ In Dennis, Three Byzantine Military Treatises, 159. The anonymous, late tenth-century Treatise on Campaign Organization, 1.49-50 (op. cit. (note 42), 249) also recommends watering horses downstream 'so the river may be kept clean further up'. 
Nor did later authors neglect to instruct generals about how to situate camps with combatants' health clearly in mind. Emperor Leo VI's Taktika, published in the early tenth century, dwells in particular on long-term military settlements, which should steer clear of wooded areas and swamps, because '[t]he rising vapors and foul smell of such places are unhealthy and bring pestilence and deadly diseases to the army' ${ }^{45}$ More than a century later, Kekaumenos' Strategikon explicitly harks back to a Hippocratic tradition in calling to avoid humid and malodorous places 'because they are prone to disease', and instructs the general to refrain from staying put for too long in one place, given the greater risk of it developing 'a bad odor and from it, diseases'. ${ }^{46}$

Finally, the mid-tenth-century Sylloge tacticorum pays ample attention to what promotes an army's health on the march, in the fort and during and under siege, dispensing advice on how best to treat the surrounding countryside (chapters 11, 53 and 55). Addressing the topic of disease prevention specifically, chapter 22 instructs the general to situate a camp away from rocky or swampy grounds and refrain from occupying the same spot at length 'due to pestilential diseases which break out from putrefaction among both horses and men'. It furthermore notes that the observation holds for all seasons except winter, when 'there is no such apprehension, due to the frozen temperature of the season' ${ }^{47}$ The treatise also elaborates on how to defend soldiers and animals from certain stratagems designed to kill them outside the context of battle. Chapters 58-61, for instance, instruct generals on how to detect and avoid food and drink poisoned for just such purposes by the enemy and strategically dispersed or left for their consumption. Another rubric (73; whose title alone has been preserved) purportedly advises on how horses and mules may obviate succumbing to pestilential disease. The entire section, finally, opens with a passage explaining how 'soldiers may easily be prevented from falling ill from sun and fatigue'. Probably building on the medical authority of Julius Africanus (160-240), it reminds the reader about the importance of feeding soldiers well as a prophylactic measure, including the rejection of wine produced in marshy - and therefore unhygienic - lands, unless it is boiled to evaporate one tenth of the liquid in order to render it healthy to drink. ${ }^{48}$

East Roman generals, in sum, much like their Latin counterparts, were encouraged to detect threats to their armies outside the context of combat and devise ways to reduce if not altogether eliminate them, building on the shared insights of ancient medical science. ${ }^{49}$

\section{Across and beyond the Mediterranean World}

Military tractates that promote community prophylactics are fairly accessible and generally well-studied for medieval western Europe and East Rome. Yet there is little reason to assume that these premodern regions were unique in that sense. As the present section begins to demonstrate, identifying and reducing hazards their underlings faced was

\footnotetext{
45 The Taktika of Leo, George T. Dennis (ed. and trans.) (Washington, DC: Dumbarton Oaks, 2010), 9.3 (195).

${ }^{46}$ Cecaumeno, Raccomandazioni e consigli di un galantuomo [Stratēgikon], Maria Dora Spadaro (ed. and trans.) (Alessandria: Edizioni dell'Orso, 1998), ch. 29 (71).

${ }^{47}$ A Tenth-Century Byzantine Military Manual: The Sylloge Tacticorum, Georgios Chatzelis and Jonathan Harris (trans.) (Abingdon and New York: Routledge, 2017), 39.

48 Ibid., 93-97 and 97.

${ }^{49}$ European and Ottoman exchanges in the field of military prophylactics lie beyond this essay's scope, but see Gábor Ágoston, 'Where Environmental and Frontier Studies Meet: Rivers, Forests, Marshes and Forts along the Ottoman-Hapsburg Frontier in Hungary', Proceedings of the British Academy, 156 (2009), 57-79. On Ottoman sultans' manoeuvring of armies to avoid entering plague-afflicted areas, see Nükhet Varlik, Plague and Empire in the Early Modern Mediterranean: The Ottoman Experience, 1347-1600 (New York: Cambridge University Press, 2015), 140-44.
} 
a responsibility claimed by many army (and civic and religious) leaders across the globe, at least insofar as it legitimised their authority and certain aspects of disciplining soldiers and related communities. My linguistic limitations prevent me from accessing evidence for many historical cultures where the hypothesis can be tested, but a few examples may suffice to propose how this path may fruitfully be pursued for the benefit of public health historians.

To begin with Europe's and East Rome's nearest neighbours in health: the vast majority of Arabic military treatises from the Middle Ages remain unpublished, untranslated and rarely studied. ${ }^{50}$ Yet, given the early Islamicate world's deep familiarity with and contribution to the Greco-Roman medical tradition, it is hardly surprising that prophylactics became a staple of Arabic military medicine. ${ }^{51}$ An early source illuminating the topicality of preventative practices outside of combat is a passage by Abu Bakr Muhammad ibn Zakariya al-Razi (aka Rhazes; 865-925). In his Kitab al-Mansouri fi al$T i b \dot{b}$, the acclaimed Persian medical scholar argued that military camps

should be pitched in summer on hills and high places, tents being directed towards the north wind, with plenty of air space between tents. Animals should be kept as far from the tents as possible. In winter the camps should be placed in low-lying places, preferably at the foot of hills or mountains, tents being directed towards the east or south, alternate pairs of tents being joined together. When moist south winds blow, rations should be cut down, wine should be interdicted, and more military exercises taken. When the air is dry, just the opposite regime should be enforced. Sick cattle should be kept far from the camp, in low windless places.... Poisonous odorous plants and trees should be burned or the camp site should be above them. Food and drink, as causing many diseases, should be inspected with great caution. ${ }^{52}$

Al-Razi was not composing a military treatise, but the above passage, which may by now ring familiar thanks to the sources it shared with medieval Latin and Greek works, underscores at least for other elites the hazards posed by natural elements, alongside other non-naturals, to garrisoned armies. It also alludes, centuries before Von Clausewitz, to the health benefits of tents.

Such insights reverberate throughout a range of Arabic tactical treatises. For instance, al-Ansari's Tafrìj al-Kurūb fì Tadbìr al-Hurūb, an early fifteenth-century military manual, likely based on a ninth-century work, stresses the importance of knowing how to conduct responsible marching and identify salubrious stations. The able general is hence to be 'experienced [with regard to handling] roads and watered places and water resources, and the conditions of way-stations and camping grounds, and the times during which marching and camping are proper'. ${ }^{53}$ The work furthermore specifies that, in choosing a campsite, sustenance (pasture, water, food, etc.) as well as tactical variety and defensibility are crucial ${ }^{54}$ and that its internal organisation should enable good communication and order. ${ }^{55}$

\footnotetext{
${ }^{50}$ Shihab al-Sarraf, 'Mamluk Furūsīyah Literature and Its Antecedents', Mamluk Studies Review, 8 (2004), 141-200. See also Carole Hillenbrand, The Crusades: Islamic Perspectives (Edinburgh: Edinburgh University Press, 1999), 435-39.

${ }^{51}$ Dols op. cit. (note 16); Pormann and Savage-Smith, op. cit. (note 16); Stearns, op. cit. (note 16).

52 Quoted here from Fielding H. Garrison, Notes on the History of Military Medicine (Washington, DC: Association of Military Surgeons, 1922), 82.

53 A Muslim Manual of War, Book 6, ch. 1, George T. Scanlon (ed. and trans.), rev. edn (Cairo and New York: American University in Cairo Press, 2012 [orig. pub. 1961]), 70.

${ }^{54}$ Ibid., Book 10, ch. 1 (86-87).

55 Ibid., Book 10, ch. 2 (87-88). For a crossover between military and urban prophylactic insights, as seen through the eyes of one Muslim military leader as he moves from central Asia into India, see The Baburnama: Memoirs of Babur, Prince and Emperor, Wheeler M. Thackston (ed. and trans.) (New York: Modern Library, 2002), 7-8, 25, 56-59, 334-35, 363-65, 397 and 428.
} 
Exploring additional sources for similar purposes is possible well beyond Europe and the Mediterranean region. Once again, and without attempting a comprehensive overview, key treatises hailing from east Asia highlight preventative considerations, for instance, in discussing how best to manoeuvre an army. Sun-tzu's Art of War, a Chinese collection codified in the early eleventh century but probably drawing on much earlier texts, observes that 'the army likes heights and abhors low areas, esteems the sunny [yang] and disdains the shady [ying]. It nourishes life and occupies the substantial. An army that avoids the hundred illnesses is said to be certain of victory'. ${ }^{56}$

And a similar prophylactic principle informs Wu-tzu's manual, an acclaimed work originating in the fourth century BC and popularised under the Han dynasty (206 BC220 AD):

Control is foremost [to ensure armies' victory...]. What is meant by control is that when stationary [i.e. in camp] they observe the forms of propriety $[l i]$ and when in action they are awesome... In general the Way [Tao] to command an army on the march is not to contravene the proper measure of advancing and stopping; not miss the appropriate times for eating and drinking; and not completely exhaust the strength of the men and horses.... If advancing and resting are not measured; if drinking and eating are not timely and appropriate; and if, when the horses are tired and the men weary, they are not allowed to relax in the encampment, then they will be unable to put the commander's orders into effect. When the commander's orders are thus disobeyed, when encamped they will be in turmoil, and in battle they will be defeated. ${ }^{57}$

Given Chinese influence on myriad aspects of Japanese culture it should come as no surprise that the broad social remit of military commanders was typical of Japanese manuals as well. As the martial artist and theoretician Miyamoto Musashi put it in 1632, 'Large-scale military science is a matter of winning at keeping good people, winning at employing large numbers of people, winning at correctness of personal conduct, winning at governing nations, winning at taking care of the populace' ${ }^{58}$ And the author of an early eighteenth-century manual lamented: 'People of all social classes, high and low, constantly overheat, drink too much, and indulge their desires to an unhealthy degree, all because of forgetting about death. This puts a strain on their internal organs, so they may die remarkably young, or else become sickly or invalid.' Reducing health risks, in sum, requires visible hygienic discipline:

The principles of knighthood include washing your hands and feet and bathing morning and night, keeping your body clean, shaving and dressing your hair every morning, dressing formally according to the season and circumstances and always keeping your fan in your belt, not to mention your long and short swords. ${ }^{59}$

Whatever their specific relations and impact, collectively such texts illustrate, first, elites' concerns about armies' vulnerabilities, and secondly, how prevention did not have to share the exact same medical or natural-philosophical paradigm across distant cultures to remain a pertinent consideration at least for army leaders. Be it on the march or in the camp, and well before the so-called professionalisation of military medicine, armies were seen as communities of prophylactic practices. As such, they strongly resembled other premodern communities at risk. ${ }^{60}$

\footnotetext{
56 The Seven Military Classics of Ancient China, Ralph D. Sawyer (ed. and trans.) with Mei-chün Sawyer (New York: Basic Books, 2007), 173.

${ }^{57}$ Ibid., 214-15.

${ }^{58}$ Miyamoto Musashi, The Book of Five Rings, Thomas Cleary (trans.) (Boston and London: Shambhala, 2000), 16.

59 Taira Shigesule, Code of the Samurai, Thomas Cleary (trans.) (Tokyo: Tuttle, 1999), 4 and 11, respectively.

60 To offer a final example from the region, among the medieval Mongols, once a soldier's death was recognised as imminent, his yurt became off limits to all but a limited few, who in turn were prohibited from contacting high-ranking persons. Yurts themselves were placed widely apart, and armies were careful not to foul rivers
} 


\section{From Military Medicine to Social History}

Tactical manuals illuminate preventative practices and medical literacy in premodernity, an era some medical historians continue to view as uniquely unhygienic. ${ }^{61}$ Given the perspective's freshness, military historians familiar with such texts may thus find themselves at the vanguard of a revisionist endeavour that could greatly benefit public health historiography ${ }^{62}$ However, in order to understand more fully what treatises on tactics can offer the latter field, it may be helpful to interrogate some of the terms and imagined trajectories still prevalent in the former. This is not to homogenise a rich and diverse historiography, but rather to highlight what is, especially among non-specialists, a common point of entry into it. In their ambitious A History of Military Medicine, Richard Gabriel and Karen Metz argue that, prior to the nineteenth century, 'the military doctor's only hope in preserving the army from disease was to prevent its outbreak in the first place'. Both before and after the so-called professionalisation of military medicine, however, promoting safety and fighting disease were hardly limited to 'doctors', as Gabriel and Metz in fact repeatedly show. Moreover, in contrast to their balanced assessment of prophylactic care in ancient armies, ${ }^{63}$ the authors treat preventative care in medieval Europe with particular suspicion, incongruent as such practices would seem with 'the nearly total disintegration of Western culture' between the third and fifteenth centuries. ${ }^{64}$ To emphasise, from their perspective, just how deep the West had sunk in this sense too, Gabriel and Metz juxtapose the region's armies with those of Byzantium, which managed to cling to Roman hygienic standards, and the persistence in the medieval Islamicate world of 'the usual hygienic practices now commonly found in military camps in almost all armies'. In western Europe, by contrast,

the low state of military medical care is demonstrated by the filthy conditions of military camps of the period. Even the simple art of field hygiene had been lost.... The combination of disorganized military structure and the low state of medical knowledge consistently combined to wreak havoc through disease on army after army over a 700-year period. It was not until 1415 that rudimentary regulations on camp hygiene finally addressed the terrible ravages of disease.... There is no evidence, however, that any of these regulations were regularly implemented. ${ }^{65}$

As the foregone essay has shown also with respect to Latin Europe, however, field hygiene was never lost, at least not at the normative level. The authors justly warn against

upstream from their camps by only drawing water in vessels. See Timothy May, The Mongol Art of War: Chinggis Khan and the Mongol Military System (Barnsley: Pen \& Sword Books, 2016), 67-68.

61 This is often done more by implication than direct assertion. See, for instance, Anke H. Schultetus, et al., 'To Heal and to Serve: Military Medical Education Throughout the Centuries', Journal of the American College of Surgeons, 202 (2006), 1005-16, whose chronological coverage, beginning in the sixteenth century, works within a modernist paradigm of formal education.

62 Civic- and bioarchaeologists working in conflict areas, such as Piers D. Mitchell (see note 14), have pointed the way. See also James Symonds, et al., War and Peasants: An Archaeology of Village Destruction and Abandonment during the Thirty Years' War in West Bohemia (Oxford: Archaeopress, forthcoming).

63 Gabriel and Metz, op. cit. (note 4), 1:29, 31, 58 (Sumer), 98-99 (Assyria), 110-14 (Israel), 131-32 (India), 165-66 (Rome).

${ }^{64}$ Ibid., 1:181. See also ibid., 2:67, which mischaracterises the medical profession of even later centuries as 'having forgotten the old Roman notion of preventative medicine', which purportedly explains why 'few commanders gave much attention to preventing disease and illness on military campaigns'.

${ }^{65}$ Ibid., 1:204. Richard A. Gabriel, Man and Wound in the Ancient World: A History of Military Medicine from Sumer to the Fall of Constantinople (Washington, DC: Potomac Books, 2012), 185-204 and 215-17, is a reiteration of the same reductionist image, which also lurks behind Roy J. Shepard, An Illustrated History of Health and Fitness, from Pre-History to our Post-Modern World (New York: Springer, 2015), 307-308. See, by contrast, the somewhat more positive evaluation in Histoire de la médicine aux armées, Vol. 1, Jean Guillermand (gen. ed.) (Paris: Charles Lavauzelle, 1982), 275-81. 
forcing the premodern world into a single mould when it comes to preventative practices. Islamicate and East Roman armies, as they rightly stress, remained active if not innovative in implementing hygienic programmes based on deeply rooted medical insights, even if their European counterparts fell far behind. Yet the diversity Gabriel and Metz purport to show is premised on employing rather different criteria for evaluating the reliability of medieval European sources than those used for other regions and subperiods. An equally open-minded reading of records documenting west-European military prophylactics, including military manuals, would probably narrow or at any rate redraw the contours of the gap between these neighbouring civilisations, whose medical-theoretical roots were after all strongly interlinked. At the very least it would have aligned with the nuanced approach of this otherwise exemplary treatment.

More importantly, however, a stance that is less strongly wedded to a narrative of Western medical (and general) decline after Late Antiquity would broaden the scope of an already vigorous historiography of medieval field medicine and military medical institutions. It would offer scholars, and historians of public health specifically, a gateway into the realm of army prophylactics, while expanding the source base for writing a social history of medicine and medical ideas. To be sure, much ground remains to be covered. First and most obviously, the production, chronology and specific relations among the manuals discussed above deserve further attention. Relatedly, texts falling under the category of tactical manuals are far more numerous. The broader corpus can in turn be fruitfully mined for further and comparative insights and examined for the transmission of ideas and debates among medical practitioners and traditions across regions, including during long campaigns (also at sea), training, sieges and occupations. There are many other prescriptive sources, moreover, whose preventative advice can be recovered, including images, regulae governing medieval military orders (Templars, Hospitallers, etc.), crusaderelated edicts touching upon the sustenance of armies, guides for pilgrims across religions and 'mirrors' for princes. ${ }^{66}$ Next, the specific relations in different times and places between prescriptive texts and social practices, in the camp and on the march, can be reassessed, for instance on the basis of narrative sources such as diaries and chronicles, documents of practice (including letters, charters and financial records), images integrated into such texts and those (including in paintings, maps, tapestries and sculpture) that stand alone, and of course human, animal, plant and structural remains. ${ }^{67}$

66 To offer just a few examples across genres: The Rule, Statutes and Customs of the Hospitallers, 1099-1310, E.J. King (ed. and trans.) (New York: AMS Press, 1981), 42, 47, 57, 77, 127, 169-70; The Rule of the Templars: The French Text of the Order of the Knights Templar, J.M. Upton-Ward (trans.) (Woodbridge, UK, and Rochester, NY: Boydell, 1992); Qustā ibn Lūqā's Medical Regime for the Pilgrims to Mecca, The Risāla fì tadbīr safar alhajj, Gerrit Bos (ed. and trans.), chs. 1, 4, 8, 11, 13 and passim (Leiden: Brill, 1992), 22-27, 38-41, 56-59, 62-67 and 72-79, respectively; Adam of Cremona, Regimen iter agentium vel peregrinantium, in Fritz Hönger (ed.), Ärztliche Verhaltungsmaßregeln auf dem Heerzug ins Heilige Land für Kaiser Friedrich II. Geschrieben von Adam v. Cremona (c.1227) (Leipzig: Robert Noske, 1913); Thomas Aquinas, De regno ad regem Cypri, 1.14 and 2.1, ed. Joseph Kenny (Bismarck, ND: Divine Providence Press, 2014), 100 and 126, respectively. See also Karl Sudhoff, 'Ärtzliche Regimina für Land- und Seereisen aus dem 15. Jahrhundert', Archiv für Geschichte der Medizin, 4 (1911), 263-81. Premodern camp life is rarely depicted in detail, certainly as compared to the era's battles and tournaments. Unique in this respect is Swiss chronicler and illustrator Diebold Schilling the Younger, whose elaborate images of sieges in the Lucerne Chronicle (1511-13) occasionally provide glimpses of non-combat routines, including cooking, washing and intimacy. The entire codex is viewable here: https://www.e-codices.ch/en/list/one/kol/S0023-2 (last accessed 11 May 2018).

${ }^{67}$ Cifuentes and García-Ballester, op. cit. (note 9), 193-99, is an object lesson. An early blueprint for illuminating the sophistication of medieval military practices is J.F. Verbruggen, The Art of Warfare in Western Europe during the Middle Ages, 2nd edn, Sumner Willard and Mrs. R.W. Southern (trans.) (London: Boydell, 1997 [orig. pub. 1954]). Verbruggen dedicated several pages to discipline on the march and in the camp (77-83) as well as to the 
Finally, an integrated strand of research into the prophylactic insights of tactical manuals can illuminate parallel and potentially cross-fertilising programmes emerging from monastic and urban contexts. In each of these environments, at-risk sites and communities formed a major concern of local regimes, charitable institutions, professional associations and informal bodies such as neighbourhoods, and often outside the context of paroxysmal events such as the early second plague pandemic (the Black Death). Interactions among such groups and shared motivations to fight the hazards they faced are possible to trace. Given their relatively large scale, as compared with many contemporary towns and cities, premodern armies could easily create city-like footprints upon a region. As Caroline Shenton notes for northwestern Europe, 'By the mid-fourteenth century, sophisticated infrastructures were rapidly installed in large siege camps, which became temporary towns in their own right, catering for the needs of the many people involved in the hostilities' ${ }^{68}$ And as Babur, the founder of the Mughal dynasty, described his siege of Samarkand in 1496: 'So many townspeople and merchants came out of Samarkand that the camp had become a regular town. Everything that one might want in a city was to be found there. ${ }^{69}$ One assumes that 'everything' included hazards as well.

Different but sizeable premodern communities regularly devised and enforced harmreductive programmes. These involved the provision of food and removal of waste, fighting air and water pollution, curbing violence and crowdedness, promoting safety standards at home, work and during travel, and monitoring residents' interaction with people, animals and matter considered dangerous, either morally (able-bodied poor, the blind, sex workers, 'lepers', Jews) or physically (horses, oxen and, above all, pigs). ${ }^{70}$ Armies', or rather military communities' knowledge and needs, often played a key role in such contexts, not only in informing preventative programmes as objects, but also in enforcing them. For instance, however modest the urbanisation of western Europe and East Rome during the early Middle Ages, as well as the more extensive parallel process in north Africa, Iberia and Sicily, local armies were often involved in promoting and protecting the growth of cities. ${ }^{71}$ Armies' more direct involvement in defending urban health emerges in other contexts as well. The metropolitan janissaries of Constantinople, for example, fought fire, guarded gates and prisons, and ensured fair trading in markets as part of their overall mission to maintain civic order. ${ }^{72}$ And with the arrival of plague in Pistoia in the early summer of 1348 , combatants were mobilised explicitly to protect the city and its hinterland from further onslaught. ${ }^{73}$ Such civic-military collaborations were deeply rooted

logistics of supplies, including food and equipment (331-38). Yet neither section discusses preventative insights, and the book generally refrains from engaging medicine. Harvé Martin and Marc Russon, Vivre sous la tente au Moyen Âge (Rennes: Ouest-France, 2010), 226-32, provide a brief and generally negative view of military camp hygiene, and generals' attention to it, on the basis of some images and chronicle descriptions of sieges. Military archaeologists may be well positioned to shed new light on camp hygiene, although excavations of temporary camps are understandably rare. See Dawn Hadley and Julian D. Richards, 'Viking Torskey: Inside the Great Army's Winter Camp', Current Archaeology, 18 (2006), 12-19; Ana Curto, et al., 'Did Military Orders Influence the General Population Diet? Stable Isotope Analysis from Medieval Tomar, Portugal', Archaeological and Anthropological Sciences (2018), https://doi.org/10.1007/s12520-018-0637-3.

${ }^{68}$ Caroline Shenton, 'The Location of the Siege Camp at Berwick-upon-Tweed, 1333', Archaeologia Aeliana, ser. 5, 29 (2001), 253-55: 254.

69 The Baburnama, op. cit. (note 55), 50. Jonathan Riley-Smith also memorably described crusading armies as monasteries on the move in 'Crusading as an Act of Love', History, 65 (1980), 177-92.

70 See notes $10-12$ above.

${ }^{71}$ Petersen, op. cit. (note 30), 300-7.

72 Godfrey Goodwin, The Janissaries (London: Saqi Books, 1997), 88-90 and 97-100.

73 Alberto Chiappelli, 'Gli Ordinamenti Sanitari del Comune di Pistoia contro la Pestilenza del 1348', Archivio Storico Italiano, ser. 4, 20 (1887), 3-24: 23 (IV). 
in urban governance, at least across western Europe. In the relatively urbanised Italian peninsula and the Low Countries, military and civic leadership strongly overlapped, as did cities' labour and fighting forces, facilitating the transmission of preventative theories and policies as well as their implementation. ${ }^{74}$ What is more, as Janna Coomans has recently shown for the later medieval Low Countries, public works and waste disposal outfits often began when under-employed troops were seconded to the city government; ${ }^{75}$ and as Sander Govaerts demonstrates with respect to the Meuse Valley, between the thirteenth and the eighteenth century armies in this region were bent on making life in cities, fort towns and villages more sustainable. ${ }^{76}$ Armies' routines, in short, can be studied profitably from the perspective of public health and further enrich the fields of medical and health history.

\section{Conclusion}

Achieving a blended (and for that matter more reliable) view of three premodern worlds, the military, the monastic and the civic, would help make one aspect of military history more directly pertinent to social, religious and health history, and vice versa. The outcome should be particularly welcome to scholars of premodern civilisations given the relative paucity of sources shedding direct light on public health in this long period. At least within a western European context, moreover, a revised view may challenge the consensus regarding the emergence, in the later eighteenth century, of a new form of power brokering dubbed by Michel Foucault and others as biopolitics. Foucauldians define biopolitics as the endeavour 'to rationalize problems presented to governmental practice by the phenomena characteristic of a group of living human beings constituted as a population: health, sanitation, birth rate, longevity, race'. ${ }^{77}$ Abundant evidence from monastic and urban milieus has already begun to undermine the chronology (but not the modality) of biopolitics as a uniquely modern European phenomenon. Studies illuminating the deployment of health discourses and preventative programmes in later medieval Portugal, the early modern Ottoman Empire and Italy, for example, situate them within competing claims to medical authority and forms of expertise that exceed the scope of traditional political elites. ${ }^{78}$ Recovering similar evidence from army life to demonstrate the ubiquity and variety of prophylactic approaches may thus expand the circle of scholars historicising biopolitics, on the one hand, and challenge a key aspect of an accepted pre/modern divide, on the other. ${ }^{79}$

\footnotetext{
74 William Caferro, 'Petrarch's War: Florentine Wages and the Black Death', Speculum, 88 (2013), 144-65; Jean-Claude Maire Vigueur, Cavaliers et citoyens: guerre, conflits et société dans l'Italie communale, XIIeXIIIe siècles (Paris: École des haute études et sciences sociales, 2014); Daniele Bortoluzzi, 'Una città davanti alla guerra. Gestione dell'emergenza e comando dell'esercito a Bologna alla fne del Duecento (1296-1306)' (unpublished PhD dissertation, Università degli Studi di Firenze and Univesità di Siena, 2018), ch. 2.

75 Janna Coomans, 'The King of Dirt: Public Health and Sanitation in Late Medieval Ghent', Urban History (2018), https://doi.org/10.1017/S096392681800024X.

${ }^{76}$ Govaerts, op. cit. (note 1).

${ }^{77}$ Michel Foucault, 'The birth of biopolitics', in Paul Rabinow (ed.), The Essential Works 1954-1984, Robert Hurley, et al. (trans.), Vol. 1, (New York: The New Press, 1997), 73-79: 73. And see Mitchell Dean, Governmentality: Power and Rule in Modern Society (London: Sage, 1999), 98-112.

${ }^{78}$ Iona McCleery, 'Medical licensing in Late Medieval Portugal', in Wendy J. Turner and Sarah M. Butler (eds), Medicine and the Law in the Middle Ages (Leiden: Brill, 2014), 196-219; Varlik, op. cit. (note 49); Geltner, op. cit. (note 11).

${ }^{79}$ See Kathleen Davis, Periodization and Sovereignty: How Ideas of Feudalism and Secularization Govern the Politics of Time (Philadelphia: University of Pennsylvania Press, 2008).
} 